\title{
Candida aechmeae sp. nov. and Candida vrieseae sp. nov., novel yeast species isolated from the phylloplane of bromeliads in Southern Brazil
}

\author{
Correspondence \\ Melissa Fontes Landell \\ melissa.landell@gmail.com
}

\author{
Melissa Fontes Landell, ${ }^{1,2}$ Raisa Billodre, ${ }^{1}$ Jesus P. Ramos, ${ }^{3}$ \\ Orílio Leoncini, ${ }^{4}$ Marilene H. Vainstein ${ }^{1,2}$ and Patrícia Valente ${ }^{1,2}$ \\ 1Departamento de Microbiologia, ICBS, Universidade Federal do Rio Grande do Sul, Porto Alegre \\ RS, Brazil
${ }^{2}$ Centro de Biotecnologia, Universidade Federal do Rio Grande do Sul, Porto Alegre RS, Brazil
${ }^{3}$ Fundação Oswaldo Cruz, Rio de Janeiro RJ, Brazil
${ }^{4}$ Instituto do Câncer, Rio de Janeiro RJ, Brazil

The Atlantic forest is one of the richest in terms of biodiversity and is also one of the most threatened. Bromeliads are typically abundant plants in the Atlantic Forest and sustain a great diversity of organisms, including yeasts and animals that can act as yeast vectors (Hagler et al., 1993; Araújo et al., 1998; Landell et al., 2006). Novel yeast species have been isolated from the water tanks and leaves of bromeliads in Brazil, showing the high microbial diversity associated with this substrate (Ruivo et al., 2005; Inácio et al., 2008; Landell et al., 2009).

During a survey of yeasts associated with bromeliads in South Brazil, two novel species of ascomycetous yeasts were isolated from the phylloplane and tank water of different bromeliads. The sequences of the D1/D2 domain of the large subunit (LSU) rRNA gene showed that these species are genetically distinct from all currently accepted ascomycetous yeasts.

Abbreviation: LSU, large subunit.

The GenBank/EMBL/DDBJ accession numbers for the sequences of the D1/D2 domain of the LSU rRNA gene of strains Bl153 ${ }^{\top}$ (=CBS $\left.10831^{\top}=\mathrm{NRRL} \quad \mathrm{Y}-48456^{\top}\right)$ and $\mathrm{BI} 146^{\top} \quad\left(=\mathrm{CBS} \quad 10829^{\top}=\mathrm{NRRL}\right.$ $\left.\mathrm{Y}-48461^{\top}\right)$ are EU678950 and EU200785, respectively.

\section{Methods}

Leaves of the bromeliads Aechmea recurvata and Billbergia nutans and samples of the tank water of the bromeliad Vriesea gigantea were collected aseptically in April and May 2004 in Itapuã Park, South of Brazil (approx. coordinates: $30^{\circ} 22^{\prime} \mathrm{S} 51^{\circ} 04^{\prime} \mathrm{W}$ ). Leaves were collected in polyethylene plastic bags, transported to the laboratory and washed with sterile distilled water. Bromeliad fragments totalling $10 \mathrm{~cm}^{2}$ were placed in Erlenmeyer flasks with $50 \mathrm{ml}$ sterile distilled water and maintained on a shaker for $10 \mathrm{~min}$. The water was discarded and replaced by $30 \mathrm{ml} 0.5 \%$ Tween 20, followed by vigorous shaking for $30 \mathrm{~min}$. This last step was repeated and decimal dilutions of the last washing were spread on acidified YM agar (1\% glucose, $0.3 \%$ malt extract, $0.3 \%$ yeast extract, $0.5 \%$ peptone, $2 \%$ agar, acidified to $\mathrm{pH} 4.0$ and supplemented with $0.04 \%$ chloramphenicol) plates. After incubation at $20-25{ }^{\circ} \mathrm{C}$ for up to 7 days, representative colonies of the different morphological types were purified and maintained on agar slants at $4{ }^{\circ} \mathrm{C}$, covered with sterile mineral oil. Phenotypic characterization of the isolates was performed according to Yarrow (1998) and Barnett et al. (2000). Ascospore formation was determined for all isolates with similar or identical D1/D2 sequences in all combina- 
tions on acetate agar and diluted $(1: 19)$ V8 agar at $25^{\circ} \mathrm{C}$ (Barnett et al., 2000) and cultures were observed periodically for up to one month.

Yeast DNA was extracted and purified according to Ramos et al. (2001). The divergent D1/D2 domain of the LSU rRNA gene was amplified with NL1 and NL4 primers (O'Donnell, 1993). Amplification conditions were as follows: one initial cycle at $94{ }^{\circ} \mathrm{C}$ for $3 \mathrm{~min} ; 33$ cycles at $95{ }^{\circ} \mathrm{C}$ for $1 \mathrm{~min}, 56{ }^{\circ} \mathrm{C}$ for $30 \mathrm{~s}, 72{ }^{\circ} \mathrm{C}$ for $1 \mathrm{~min}$ and a final extension cycle at $72{ }^{\circ} \mathrm{C}$ for $6 \mathrm{~min}$. The PCR products were examined by electrophoresis on a $1 \%$ agarose gel at $100 \mathrm{~V}$ for $45 \mathrm{~min}$ and stained with ethidium bromide for visualization under UV light.

The sequences of two strains, BI $146^{\mathrm{T}}$ and $\mathrm{BI} 153^{\mathrm{T}}$, were obtained with Amersham MegaBACE 1000 automated sequencers using standard protocols at the facilities of the Brazilian Genome Network at the Center of Biotechnology, Cbiot-UFRGS-RS, Brazil, and Instituto do Cancer, RJ, Brazil, respectively. Alignments and phylogenetic trees were constructed with MEGA4 (Tamura et al., 2007) using the neighbour-joining and maximum-parsimony methods, with bootstrap values based on 1000 random samplings.

PCR-fingerprinting followed the protocols described by Sampaio et al. (2001) using the primer $(\mathrm{GTG})_{5}$. Gel electrophoresis images were acquired with GelDoc XR System Software (Bio-Rad).

\section{Results and discussion}

Three anamorphic ascomycetous yeast strains isolated from bromeliads, strains $\mathrm{BI} 153^{\mathrm{T}}$, BI259 and $\mathrm{BI} 146^{\mathrm{T}}$, were characterized by PCR fingerprinting with primer (GTG) 5 . The profiles of strains $\mathrm{BI} 153^{\mathrm{T}}$ and BI259, isolated from the phylloplane of $A$. recurvata and $B$. nutans, respectively, were identical, suggesting conspecificity. The profile of strain BI146 ${ }^{\mathrm{T}}$, isolated from the water tank of $V$. gigantea differed from those of strains BI $153^{\mathrm{T}}$ and BI259 (data not shown). D1/D2 sequencing of isolate $\mathrm{BI} 153^{\mathrm{T}}$ confirmed that it belonged to a novel yeast species. When compared with the closest match for the D1/D2 domain of the LSU rRNA gene sequence, Candida ubatubensis, 18 base substitutions were found, indicating that these species are phylogenetically distinct. Phylogenetic placement of strain $\mathrm{BI} 153^{\mathrm{T}}$ differed in neighbour-joining (Fig. 1) and maximum-parsimony (data not shown) trees, but it always clustered with C. ubatubensis. Strain BI259 was considered to belong to the same taxon as strain $\mathrm{BI} 153^{\mathrm{T}}$ based on their $\mathrm{GTG}_{5}$ fingerprinting patterns and their identical phenotypic characteristics. This novel species was named Candida aechmeae sp. nov. and it could be differentiated from $C$. ubatubensis by differing results in tests for the assimilation of L-arabinose, raffinose, inulin and citrate. C. ubatubensis was isolated from the water tank of the bromeliad Canistropsis sidelii in an Atlantic rainforest in South-east Brazil (Ruivo et al., 2005), suggesting that C. ubatubensis and Candida aechmeae sp. nov. may represent a cluster of novel ascomycetic yeast species associated with bromeliads.

D1/D2 sequencing of isolate $\mathrm{BI} 146^{\mathrm{T}}$ confirmed that it also belonged to a novel yeast species, named Candida vrieseae sp. nov. Phylogenetic trees constructed using neighbourjoining (Fig. 2) and maximum-parsimony (data not shown) methods placed the strain within a group of species isolated from the guts of a variety of insects and

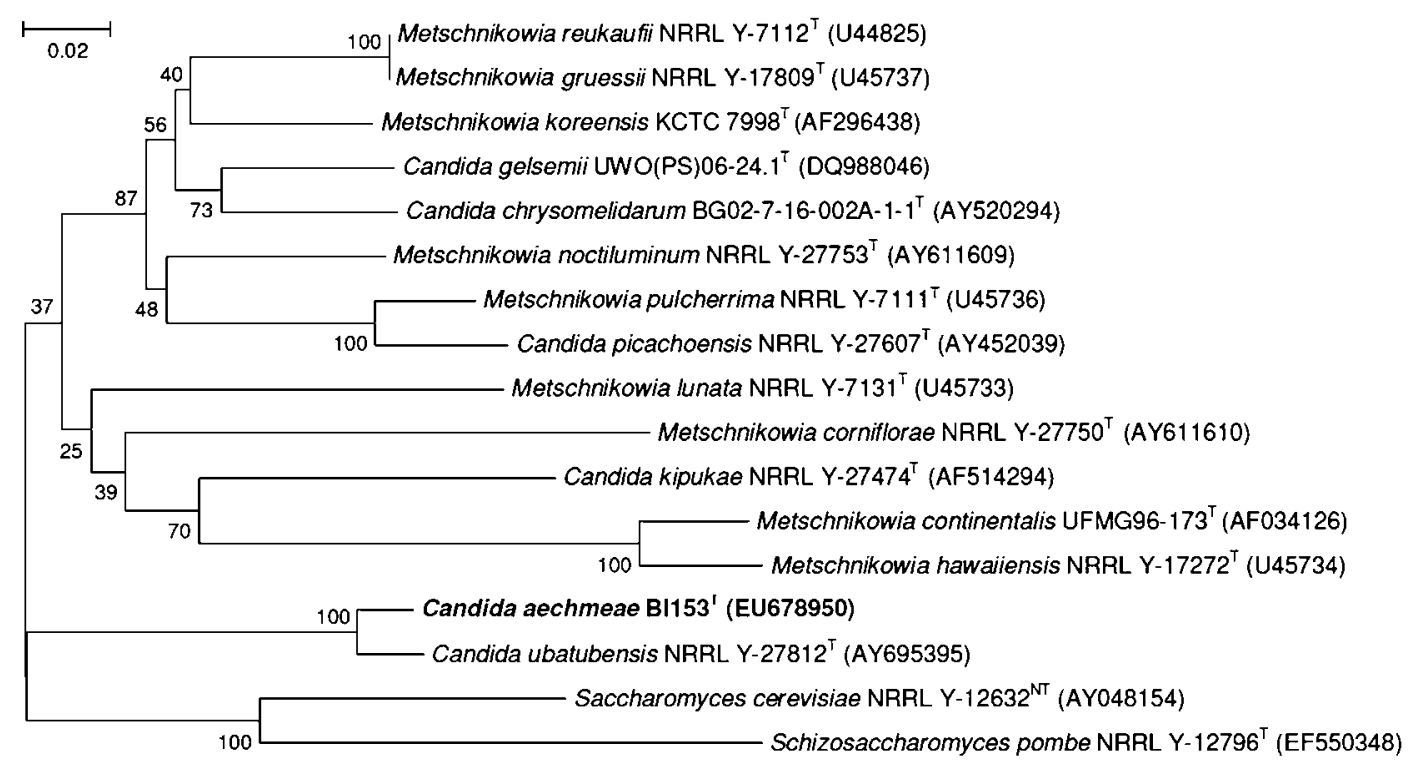

Fig. 1. D1/D2 tree showing the phylogenetic placement of Candida aechmeae sp. nov., obtained by neighbour-joining analysis using MEGA 4.0. The numbers given on the branches are the frequencies with which a given branch appeared in 1000 bootstrap replications. Bar, 0.02 substitutions per nucleotide position. 


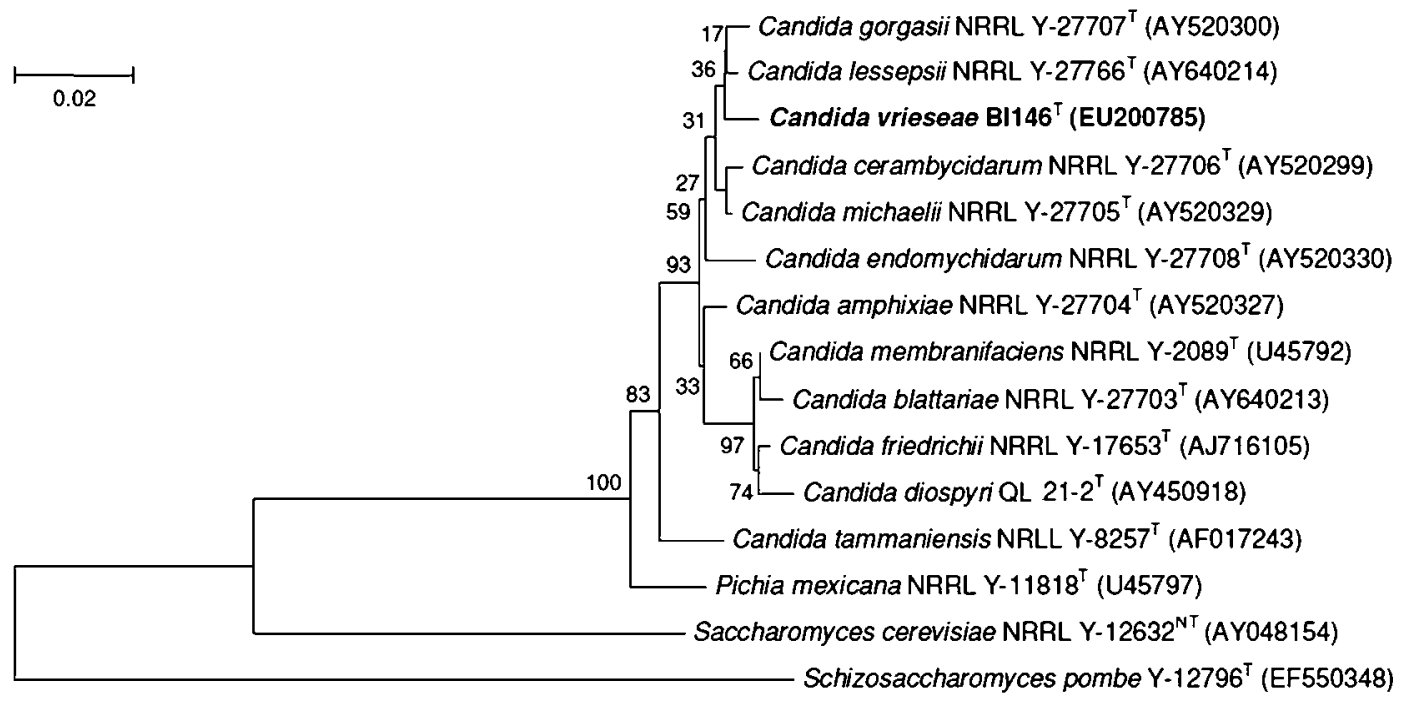

Fig. 2. D1/D2 tree showing the phylogenetic placement of Candida vrieseae sp. nov. obtained by neighbour-joining analysis using MEGA 4.0. The numbers given on the branches are the frequencies with which a given branch appeared in 1000 bootstrap replications. Bar, 0.02 substitutions per nucleotide position.

closely related to Candida membranifaciens (Suh et al., 2005), although the bootstrap values were low. This phylogenetic placement was confirmed by the ITS tree (data not shown). Strain BI146 ${ }^{\mathrm{T}}$ had 5 base substitutions in the D1/D2 region and 11 and 13 substitutions in the ITS region compared with the closest sequence matches, Candida gorgasii and Candida lessepsii, respectively. The physiological characteristics that differentiate the novel isolate from the recognized species can be seen in Table 1 . It has been suggested by Suh et al. (2005) that this group of yeasts diversified in association with insects. Therefore it cannot be ruled out that strain $\mathrm{BI} 146^{\mathrm{T}}$ may have reached the water tank of $V$. giganteae by means of an insect vector.

Although it is desirable that the description of novel species is based on a number of isolates that could represent the variability within the species, rare species are not uncommon in nature. C. aechmeae sp. nov. and C. vrieseae sp. nov. are two novel rare ascomycetous yeast species isolated from bromeliads during a three-year survey in Itapuã Park, Brazil. Therefore, their descriptions are based on only a few isolates as a direct consequence of the rarity of both novel species.

\section{Latin diagnosis of Candida aechmeae Landell et Valente sp. nov.}

In medio liquido dextroso, peptono et extracto fermenti continente post 7 dies ad $25{ }^{\circ} \mathrm{C}$ cellulae vegetativae ellipsoideae et ovoideae, 3-6.5 $\times 2-4.5 \mu \mathrm{m}$, singulae vel binae. Cultura in GYP agaro post dies 7 ad $25{ }^{\circ} \mathrm{C}$ albida et butyrosa. In agaro farinae Zea mays post dies 21 mycelium et pseudomycelium formantur. Asci non formantur. Glucosum et galactosum fermentantur. Glucosum, galactosum, D-ribosum, D-xylosum,
L-arabinosum, L-rhamnosum, sucrosum, maltosum, cellobiosum, salicinum, raffinosum, inulinum, glycerolum, erythritolum, ribitolum, glucitolum, mannitolum, acidum succinicum, citratum, N-acetylglucosaminum assimilantur. D-Arabinosum, trehalosum, melibiosum, lactosum, amylum solubile, meso-inositolum, acidum gluconicum, acidum lacticum non assimilantur. Natrii nitritum et lysinum assimilantur, sed non

Table 1. Differential physiological characteristics of Candida vrieseae sp. nov. and related species

Taxa; 1, Candida vrieseae sp. nov.; 2, Candida cerambycidarum; 3, Candida gorgasii; 4, Candida michaelii; 5, Candida endomychidarum; 6, Candida lessepsii. Data for taxa 2-5 are taken from Suh et al. (2005). +, Positive; -, negative; D, delayed reaction; W, weak reaction.

\begin{tabular}{|c|c|c|c|c|c|c|}
\hline Characteristic & 1 & 2 & 3 & 4 & 5 & 6 \\
\hline \multicolumn{7}{|c|}{ Assimilation of carbon compounds } \\
\hline D-Ribose & - & + & $\mathrm{D}$ & - & D & + \\
\hline L-Arabinose & + & + & + & + & + & $\mathrm{D}$ \\
\hline D-Arabinose & - & $\mathrm{w}$ & $\mathrm{D}$ & - & + & + \\
\hline L-Rhamnose & + & + & + & + & + & - \\
\hline Lactose & - & - & + & - & - & - \\
\hline DL-Lactate & - & $\mathrm{D}$ & $\mathrm{w}$ & + & D & - \\
\hline \multicolumn{7}{|c|}{ Assimilation of nitrogen compounds } \\
\hline Nitrite & + & - & - & - & - & - \\
\hline Ethylamine & - & + & + & + & + & + \\
\hline \multicolumn{7}{|l|}{ Growth with } \\
\hline $50 \%$ D-Glucose & - & + & - & + & + & + \\
\hline $10 \% \mathrm{NaCl}$ & + & + & + & + & + & + \\
\hline $16 \% \mathrm{NaCl}$ & - & $\mathrm{w}$ & - & - & + & $\mathrm{W}$ \\
\hline
\end{tabular}


natrii nitratum, ethylaminum, creatinum et creatininum. Non crescit in $37{ }^{\circ} \mathrm{C}$. In medio cum $50 \%$ glucosum non crescit. Materia amyloidea iodophila non formatur. Ureum non hydrolysatur. Reactio Diazonii coerulei B non respondens.

Typus: BI153 ${ }^{\mathrm{T}}\left(=\mathrm{CBS} 10831^{\mathrm{T}}=\mathrm{NRRL} \mathrm{Y}-48456^{\mathrm{T}}\right)$ designat stirpem typicam. Isolata ex folio bromeliaceae, Itapuã Park, Brazil. Preservatus in collectione Centraalbureau voor Schimmelcultures, Trajectum ad Rhenum.

\section{Description of Candida aechmeae Landell \& Valente sp. nov.}

Candida aechmeae (aech.me'ae. N.L. n. Aechmea a botanical genus name; N.L. gen. n. aechmeae of Aechmea, isolated from the bromeliad Aechmea recurvata).

In GYP broth after 7 days at $25{ }^{\circ} \mathrm{C}$, the asexual cells are ellipsoidal and ovoid, 3-6.5 $\times 2-4.5 \mu \mathrm{m}$ and occur singly, in parent-bud pairs (Fig. 3a). On GYP agar, after 1 week at $25{ }^{\circ} \mathrm{C}$, the streak culture is white, smooth and butyrous. After 3 weeks in Dalmau plate culture on cornmeal agar, pseudomycelium and true mycelium are formed (Fig. 3b). Asci are not formed on common sporulation media. Glucose and galactose fermentation are positive. Assimilation of carbon compounds: D-glucose, galactose, ribose, xylose, L-arabinose, L-rhamnose, sucrose, maltose, cellobiose, salicin, raffinose, inulin, glycerol, meso-erythritol, ribitol, D-glucitol, mannitol, succinic acid, citrate and $\mathrm{N}$-acetylglucosamine are assimilated; no growth occurs on $\mathrm{D}$-arabinose, trehalose, melibiose, lactose, soluble starch, inositol, D-gluconic acid or lactate. Assimilation of nitrogen compounds: sodium nitrite (variable) and lysine are assimilated; no growth on sodium nitrate, ethylamine, creatine or creatinine. No growth at $37^{\circ} \mathrm{C}$. Gelatin liquefaction and casein hydrolysis are negative. Growth on GYP broth with $10 \%(\mathrm{w} / \mathrm{v}) \mathrm{NaCl}$ is positive, but no growth with $16 \% \mathrm{NaCl}$. Growth on $50 \%$ glucose/yeast extract/peptone agar is negative. Production of starch-like compounds is negative. Urease activity and Diazonium Blue $\mathrm{B}$ reaction are negative.

The type strain was isolated from leaves of bromeliads in Itapuã Park, Rio Grande do Sul, Brazil. The type strain, BI153 ${ }^{\mathrm{T}} \quad\left(=\mathrm{CBS} \quad 10831^{\mathrm{T}}=\mathrm{NRRL} \quad \mathrm{Y}-48456^{\mathrm{T}}\right)$, has been deposited in the Yeast Collection of the Centraalbureau voor Schimmecultures, Utrecht, The Netherlands, and the ARS Culture Collection, USA.

\section{Latin diagnosis of Candida vrieseae Landell et Valente sp. nov.}

In medio liquido dextroso, peptono et extracto fermenti continente post 7 dies ad $25{ }^{\circ} \mathrm{C}$ cellulae vegetativae ellipsoideae et ovoideae, 3-4.5 $\times 2-3.5 \mu \mathrm{m}$, singulae vel binae. Cultura in GYP agaro post dies 7 ad $25{ }^{\circ} \mathrm{C}$ albida et butyrosa. In agaro farinae Zea mays post dies 21 mycelium nec pseudomycelium non formantur. Asci non formantur. Glucosum et galactosum fermentantur. Glucosum, galactosum, D-xylosum, L-arabinosum, L-rhamnosum, sucrosum, maltosum, trehalosum, cellobiosum, salicinum, raffinosum, inulinum, glycerolum, erythritolum, ribitolum, glucitolum, mannitolum, acidum gluconicum, acidum succinicum, citratum, $N$-acetylglucosaminum assimilantur. D-Ribosum, D-arabinosum, melibiosum, lactosum, amylum solubile, meso-inositolum, acidum lacticum non assimilantur. Natrii nitritum et lysinum assimilantur, sed non natrii nitratum, ethylaminum, creatinum et creatininum. Augmentum in $37{ }^{\circ} \mathrm{C}$, non crescit in $40{ }^{\circ} \mathrm{C}$. In medio cum $50 \%$ glucosum non crescit. Materia amyloidea iodophila non formatur. Ureum non hydrolysatur. Reactio Diazonii coerulei $B$ non respondens.

Typus: $\mathrm{BI} 146^{\mathrm{T}}\left(=\mathrm{CBS} 10829^{\mathrm{T}}=\mathrm{NRRL} \mathrm{Y}-48461^{\mathrm{T}}\right)$, designat stirpem typicam. Isolata ex aquam in bromeliaceae, Itapuã Park, Brazil. Preservatus in collectione Centraalbureau voor Schimmelcultures, Trajectum ad Rhenum.

\section{Description of Candida vrieseae Landell \& Valente sp. nov.}

Candida vrieseae (vrie.se'ae. N.L. n. Vriesea a botanical genus name; N.L. gen. n. vrieseae of Vriesea, isolated from the tank water of the bromeliad Vriesea gigantea).

In GYP broth after 7 days at $25{ }^{\circ} \mathrm{C}$, the vegetative cells are ellipsoidal and ovoid, 3-4.5 $\times 2-3.5 \mu \mathrm{m}$ and occur singly, in parent-bud pairs (Fig. 3c). On GYP agar, after 1 week at $25{ }^{\circ} \mathrm{C}$, the streak culture is white, smooth and butyrous. After 3 weeks in Dalmau plate culture on cornmeal agar, pseudomycelium or true mycelium are not formed. Asci are not formed on common sporulation media. Fermentation of glucose and galactose is positive. Assimilation of carbon compounds: D-glucose, galactose, xylose, L-arabinose, L-rhamnose, sucrose, maltose, trehalose, cellobiose, salicin, raffinose, inulin, glycerol, mesoerythritol, ribitol, D-glucitol, mannitol, D-gluconic acid, succinic acid, citrate and $\mathrm{N}$-acetylglucosamine are assimilated; no growth occurs on ribose, D-arabinose, melibiose,

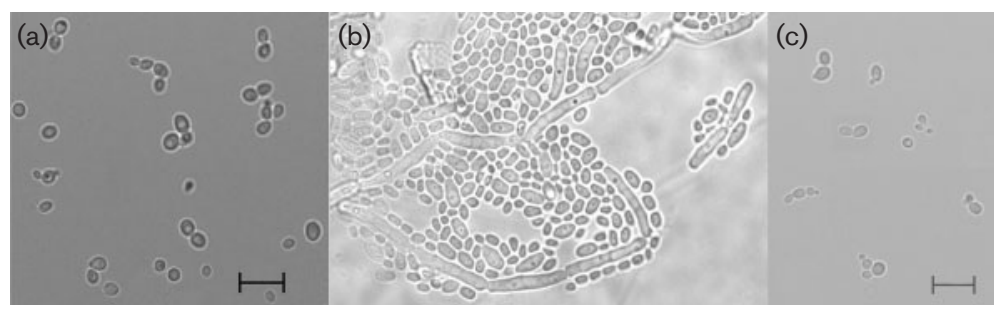

Fig. 3. (a) Budding yeast cells of strain $\mathrm{BI} 153^{\mathrm{T}}$ on GYP agar at $25{ }^{\circ} \mathrm{C}$ after 7 days; (b) pseudomycelium of strain $\mathrm{Bl}^{153^{\top}}$ on cornmeal agar at $25{ }^{\circ} \mathrm{C}$ after three weeks; (c) budding yeast cells of strain $\mathrm{Bl} 146^{\top}$ on GYP agar at $25^{\circ} \mathrm{C}$ after 7 days. Bars, $10 \mu \mathrm{m}$. 
lactose, soluble starch, inositol or lactate. Assimilation of nitrogen compounds: lysine and sodium nitrite are assimilated; no growth on sodium nitrate, ethylamine, creatinine or creatine. Grows at $37{ }^{\circ} \mathrm{C}$. Gelatin liquefaction is negative and casein hydrolysis is positive. Growth on GYP broth with $10 \%(\mathrm{w} / \mathrm{v}) \mathrm{NaCl}$ is positive; no growth with $16 \% \mathrm{NaCl}$. Growth on $50 \%$ glucose/yeast extract/ peptone agar is negative. Production of starch-like compounds is negative. Urease activity and Diazonium Blue $\mathrm{B}$ reaction are negative.

The type strain, BI146 ${ }^{\mathrm{T}}\left(=\mathrm{CBS} 10829^{\mathrm{T}}=\mathrm{NRRL} \mathrm{Y}-48461^{\mathrm{T}}\right.$ ), was isolated from tank water of bromeliads in Itapuã Park, Rio Grande do Sul, Brazil. The type strain has been deposited in the Yeast Collection of the Centraalbureau voor Schimmecultures, Utrecht, The Netherlands, and the ARS Culture Collection, USA.

\section{Acknowledgements}

The authors are thankful for the financial support from the Fundação de Amparo a Pesquisa do Rio Grande do Sul (Fapergs - process no. 02/1754-0) and the Conselho Nacional de Desenvolvimento Científico e Tecnológico (CNPq - process no. 477528/2003-1) and to the Brazilian Genome Network for use of their sequencing facilities. M. F. L. received a fellowship from CAPES.

\section{References}

Araújo, F. V., Medeiros, R. J., Mendonça-Hagler, L. C. \& Hagler, A. N. (1998). A preliminary note on yeast communities of bromeliad-tank waters of Rio de Janeiro, Brazil. Rev Microbiol 29, 118-121.

Barnett, J. A., Payne, R. W. \& Yarrow, D. (2000). Yeasts: Characteristics and Identification, 3rd edn. Cambridge: Cambridge University Press.

Hagler, A. N., Rosa, C. A., Morais, P. B., Mendonça-Hagler, L. C., Franco, G. M., Araújo, F. V. \& Soares, C. A. (1993). Yeasts and coliform bacteria of water accumulated in bromeliads of mangrove and sand dune ecosystems of southeast Brazil. Can J Microbiol 39, 973-977.
Inácio, J., Landell, M. F., Valente, P., Wang, P. H., Wang, Y. T., Yang, S. H., Manson, J. S., Lachance, M., Rosa, C. A. \& Fonseca, A. (2008). Farysizyma gen. nov., an anamorphic genus in the Ustilaginales to accommodate three novel epiphytic basidiomycetous yeast species from America, Europe and Asia. FEMS Yeast Res 8, 499-508.

Landell, M. F., Mautone, J. N. \& Valente, P. (2006). Biodiversity of yeasts associated to bromeliads in Itapuã Park, Viamão/RS. Biociencias 14, 144-149.

Landell, M. F., Inácio, J., Fonseca, A., Vainstein, M. H. \& Valente, P. (2009). Cryptococcus bromeliarum sp. nov., an orange-coloured basidiomycetous yeast isolated from bromeliads in Brazil. Int J Syst Evol Microbiol 59, 910-913.

O'Donnell, K. (1993). Fusarium and its near relatives. In The Fungal Holomorph: Mitotic, Meiotic and Pleomorphic Speciation in Fungal Systematics, pp. 225-233. Edited by D. R. Reynolds \& J. W. Taylor. Wallingford, UK: CAB International.

Ramos, J. P., Valente, P., de Souza, R. A., Rosa, C. A. \& Leoncini, O. (2001). Heteroduplex mobility assay of the D1/D2 region of the $26 \mathrm{~S}$ rDNA for differentiation of Saccharomyces species. Lett Appl Microbiol 33, 206-210.

Ruivo, C. C. C., Lachance, M. A., Rosa, C. A., Bacci, M., Jr \& Pagnocca, F. (2005). Candida bromeliacearum sp. nov. and Candida ubatubensis sp. nov., two yeast species isolated from the water tanks of Canistropsis seidelli (Bromeliaceae). Int J Syst Evol Microbiol 55, 22132217.

Sampaio, J. P., Gadanho, M., Santos, S., Duarte, F. L., Pais, C., Fonseca, A. \& Fell, J. W. (2001). Polyphasic taxonomy of the basidiomycetous yeast genus Rhodosporidium: Rhodosporidium $\mathrm{kra}$ tochvilovae and related anamorphic species. Int J Syst Evol Microbiol 51, 687-697.

Suh, S.-O., Nguyen, N. H. \& Blackwell, M. (2005). Nine new Candida species near C. membranifaciens isolated from insects. Mycol Res 109, 1045-1056.

Tamura, K., Dudley, J., Nei, M. \& Kumar, S. (2007). MEGA4: Molecular evolutionary genetics analysis (MEGA) software version 4.0. Mol Biol Evol 24, 1596-1599.

Yarrow, D. (1998). Methods for the isolation and identification of yeasts. In The Yeasts - a Taxonomic Study, 4th edn, pp. 77-100. Edited by C. P. Kurtzman \& J. W. Fell. Amsterdam: Elsevier. 